\title{
Endangered Waterbirds at Doñana Natural Space
}

\author{
Manuel Máñez, Luis García, Fernando Ibáñez, Héctor Garrido, Juan \\ Manuel Espinar, José Luis Arroyo, José Luis Del Valle, Alfredo Chico, \\ Antonio Martínez, and Rubén Rodríguez
}

\section{Background Information}

The declarations of both Doñana Biological Reserve in 1964 and Doñana National Park in 1969 were based mainly on the presence of the Iberian lynx Lynx pardinus and the Spanish imperial eagle Aquila adalberti: two species endemic to the Iberian Peninsula that have been very scarce for some time (see Valverde 1960). Of equal importance were the many species of waterbirds that use the area (see García et al. 2000; Garrido et al. 2004), many of which are nationally or internationally threatened species (Madroño et al. 2004; BirdLife International 2008).

In 1989, the area was declared Doñana Natural Park, and, in 1999, Doñana Natural Space (DNS from here on) came into existence - a legal entity that includes the Natural Park, National Park and its protection zones (Fig. 30.1). The area is also designated as a Biosphere Reserve (UNESCO), a Wetland of International Importance of the Ramsar Convention, an Important Bird Area (IBA), a World Heritage Site and a Site of Community Interest.

DNS occupies 108,087 ha, with natural, temporary marshes that flood each autumn-winter (fed by rainwater and streams) forming $47.5 \%$ of the area: these start reducing in depth and area through spring, and dry up in summer (see Valverde 1960). However 1,160 ha have been converted into industrial saltpans, and 2,971 ha into ponds for extensive aquaculture, located mainly at Veta la Palma. Neither of these is dependent on rainfall, both acquire water from the Guadalquivir River. In addition, in the northern zone, 1,398 ha of wetlands have been converted into rice fields.

M. Máñez(*), L. García, F. Ibáñez, H. Garrido, J.L. Arroyo, J.L. Del Valle, A. Chico, A. Martínez, and R. Rodríguez

Equipo de Seguimiento de Procesos Naturales, Estación Biológica de Doñana-CSIC, Avda.

Américo Vespucio s/n, Isla de la Cartuja, Sevilla, 41092, Spain

e-mail: mmanez@ebd.csic.es (M. Máñez)

J.M. Espinar

Espacio Natural de Doñana, Centro Administrativo El Acebuche, Matalascañas, 21760, Spain 


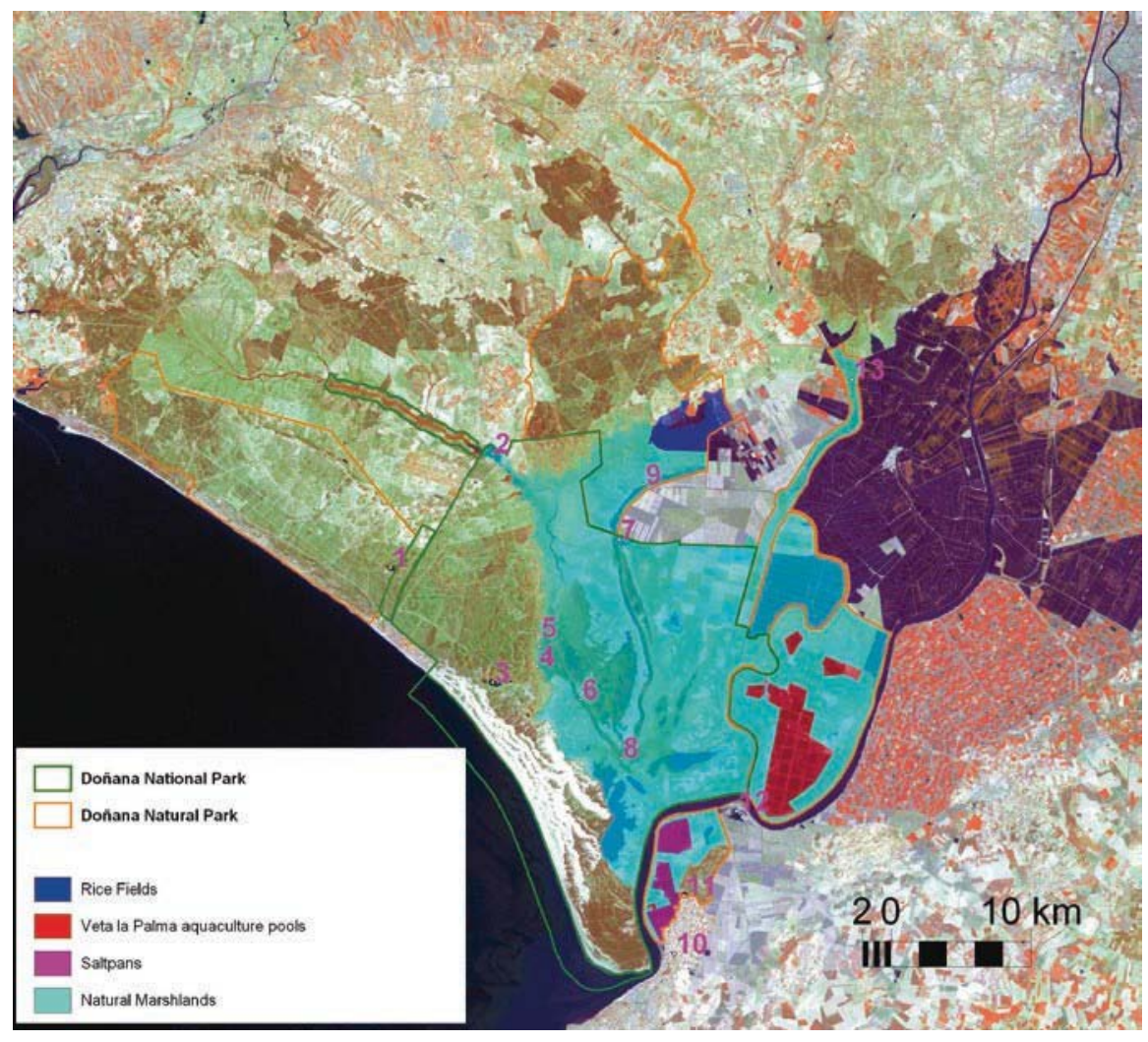

Fig. 30.1 Map of the Doñana Natural Space. The numbers indicate the approximate location of places cited in the text: 1 - El Acebuche lagoon complex; 2 - El Rocío Marshes; 3 - interdunal lagoons; 4 - Doñana Palace; 5 - Pajarera; 6 - Caño (marsh channel) of La Madre; 7 - Lucios (large depressions in the lower marshes) of FAO; 8 - Juncabalejo; 9 - Caño (marsh channel) of Guadiamar; 10 - Bonanza lagoons; 11 - Tarelo lagoon; 12-Codo de la Esparraguera; 13 - Ford of Don Simón

The remaining area of DNS represents aeolian deposits (Montes et al. 1998), the so-called "cotos", where Mediterranean scrub predominates, in a mosaic with extensive areas of cork oak Quercus suber and pine forest Pinus pinea and a large number of lagoons (Bravo and Montes 1993). While the majority of these lagoons are temporary, the interdunal lagoons are exceptional for being large and either permanent or semi-permanent.

Other lagoons of interest in DNS are the Tarelo lagoon and the lagoon complex at El Acebuche. The former is a permanent artificial lagoon, where water from the aquifer reaches the surface in an area where aggregates were mined during the 1980s. By contrast, the El Acebuche complex is a lagoon-marsh system that, after suffering a process of drainage in the 1950s, was restored during the 1970s and 1980s.

In this chapter, in addition to DNS, we cover two small wetlands located very close to the Cadiz sector of the Natural Park (Fig. 30.1): the Codo de la Esparraguera 
(Trebujena), formed by marshland that has been converted into aquaculture ponds, and three lagoons at Bonanza (Sanlúcar de Barrameda), which have the same origin as the Tarelo lagoon.

The hydrological status of the natural wetlands depends basically on rainfall. The Palacio de Doñana meteorological station maintains a complete record of the total rainfall (in mm) during the crop or hydrometeorological year (from 1st September to 31st August of the following year). The meteorological station also records the rainfall registered during winter months (from 1st September to 31st March): most of the annual rainfall needed to fill the marshes occurs in this period. As illustrated in Fig. 30.2, this varies greatly, and determines the degree of wetland flooding and, by association, the availability of habitat for waterbirds. In order to evaluate the recorded rainfall, we have compared the values with the historical annual average ( $551.57 \mathrm{~mm}, \mathrm{n}=28)$ and historical average during the autumn-winter months $(420.15 \mathrm{~mm}, \mathrm{n}=28)$.

This paper focuses on the seven species of waterbird that are classified as "Endangered": this category carries the maximum threat of extinction from a legal perspective in Spain (according to the National Catalogue of Threatened Species). These seven species are marbled teal Marmaronetta angustirostris, ferruginous duck Aythya nyroca, white-headed duck Oxyura leucocephala, bittern Botaurus stellaris, squacco heron Ardeola ralloides, black stork Ciconia nigra and redknobbed coot Fulica cristata.

The three ducks species are also threatened at a global level, although in different categories: ferruginous duck is classified as "Near Threatened", marbled teal as "Vulnerable" and white-headed duck as "Endangered" (BirdLife International 2008).

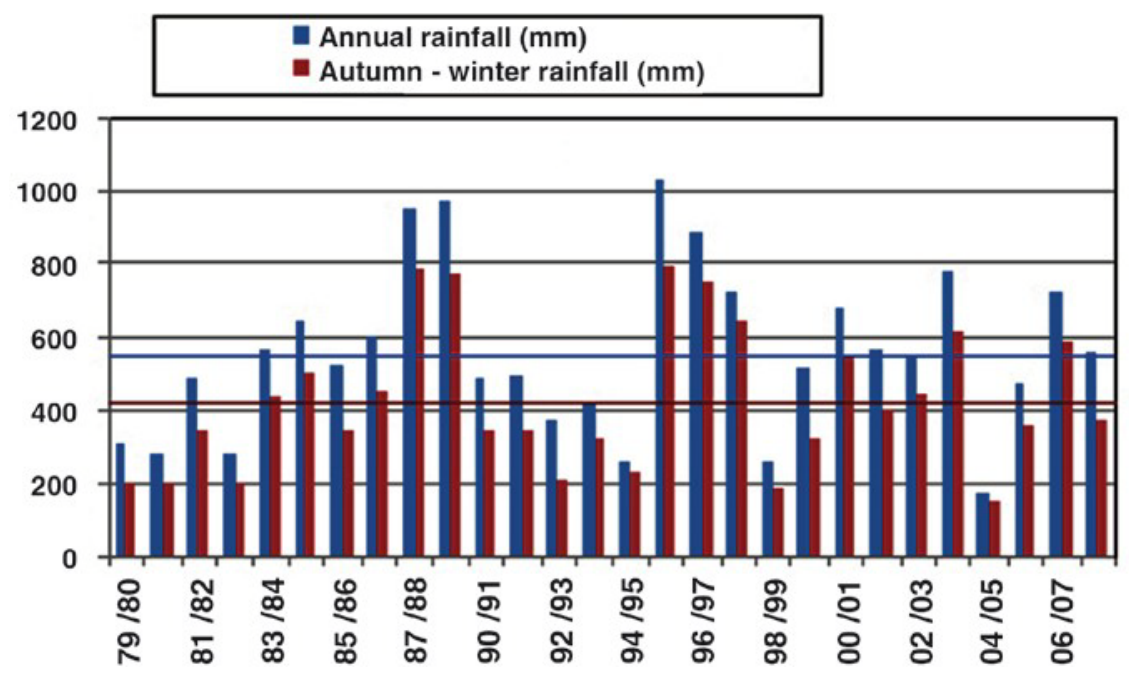

Fig. 30.2 Annual rainfall (in blue) and autumn-winter rainfall (in red) recorded at the Palacio de Doñana meteorological station from 1979/80 to 2007/08 (does not show the rainfall of 1988/89, as this was not measured in its entirety). This also shows the historical annual average (blue line) and historical average during the months of autumn-winter (red line) 


\section{The Methods}

The main reason for monitoring these species is to determine the size of the population in DNS, especially during the breeding season, and to detect any trends that evolve over time. The method used is species-dependent, and is always based on a systematic survey of the entire natural wetland. This information is then supplemented with detailed surveillance of the nests, family groups (territorial males in the case of the bittern) and wintering birds. The marsh survey is carried out mainly on horseback and, in the case of the red-knobbed coot, using a “cajón” (a flat-bottomed boat propelled by poles). The census method involves a direct count of the bird flock settled in each of the wetlands: a method used for the majority of the waterbirds (Tellería 1986; Sutherland 1996). The count is performed from fixed locations (or by fixed route), depending on the size of the wetland and the existence of observation points.

The three duck species and the red-knobbed coot are also censused nationally in the middle of January, April, June, September and November. When pairs or nests of these species are detected, they are monitored throughout the breeding season.

The breeding population of the bittern is surveyed by locating 'booming' territorial males, systematically covering the entire wetland on horseback during the relevant period.

The breeding population of the squacco heron is censused by counting the nests or pairs in the breeding colonies from suitable locations.

Finally, we census the wintering population of black storks, taking account of data from the international census in January. This census covers all the wetlands on the right bank of the Guadalquivir river, both DNS and neighbouring areas that have been converted into rice fields or are used for the farming of other crops, and the Dehesa de Abajo Concerted Nature Reserve, as well as the main wetlands on the left bank.

The data are derived mainly from the archives of the Bird Section of the Natural Processes Monitoring Team (EBD-CSIC), which collaborates with the administrations managing DNS.

We have used TRIM (Trends \& Indices for Monitoring Data; Pannekoek and Van Strien 1998) to analyse population trends: this is a statistical program designed for analysing data for wild populations. This program determines if the observed trend could be due to chance or not, and if not, determines the signal of the trend and the index of annual increase or decrease, taking the first year of sampling as the base year (100\%).

\section{Results by Species}

\section{Marbled Teal}

Censuses show that the population trend from 2003/2004 to 2007/2008 has a similar pattern (low numbers in September, a peak in November, almost total absence in January, slight increase in April and larger increase in June), except 2006/2007 
when very few ducks were seen. The Strait of Gibraltar is not a great barrier for the species, and flocks move between Morocco and Western Andalusia at any time of year, depending on changes in habitat availability (Green et al. 2004).

Marbled teal was the most abundant of the nesting ducks in these wetlands at the end of the nineteenth century. By the 1950s, however, only 100-200 pairs remained in years of average rainfall (Valverde 1960). During the 1970s, there was another marked decline, and by the end of that decade the breeding population was estimated at only 10-20 pairs.

Thereafter, following a drought in the early 1980s (Fig. 30.2), the breeding population recovered to over 100 pairs between 1984 and 1988, before falling again during a drought at the beginning of the 1990s, when the population reached its lowest level: in 1995 not a single pair was found in the Gualdalquivir Marshes (see Navarro and Robledano 1995; Green et al. 2004).

Between 1996 and 2008, estimates suggest that the maximum number of pairs in the area fluctuated between 10 and 83 (Fig. 30.3). The low numbers in 1996 can be explained by a severe drought that occurred over the previous 5 years, and the low numbers in 1999 and 2005 can be explained by extreme droughts in the previous winters (Fig. 30.2): the rainfall was not sufficient to flood the natural wetland and the Veta la Palma aquaculture pools and, during dry years, the salinity level is too high for breeding ducks (Green 2000).

Nevertheless, the low numbers since 2006 are worrying, since the predicted recovery after years of average and high rainfall (Fig. 30.2) has not materialised.

As far as broods are concerned, the estimates ranged from 2 to 31 (Fig. 30.3), with considerable differences between the numbers of pairs and the number of
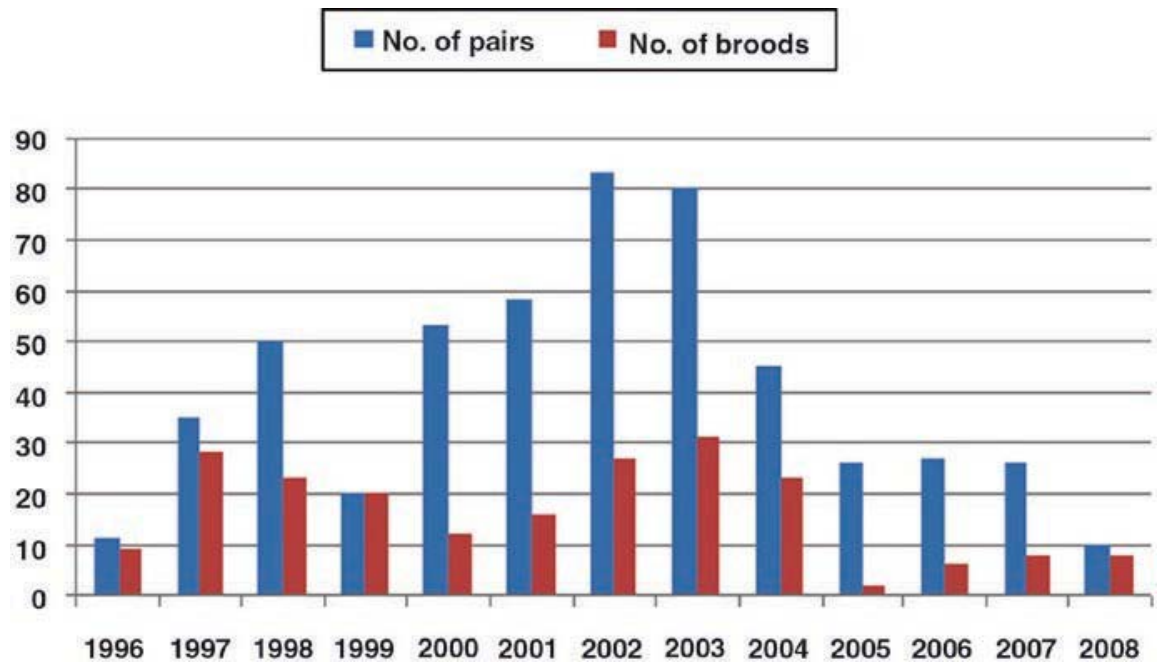

Fig. 30.3 Number of estimated pairs and number of estimated broods of marbled teal at Doñana Natural Space and other nearby wetlands over the period from 1996 to 2008 


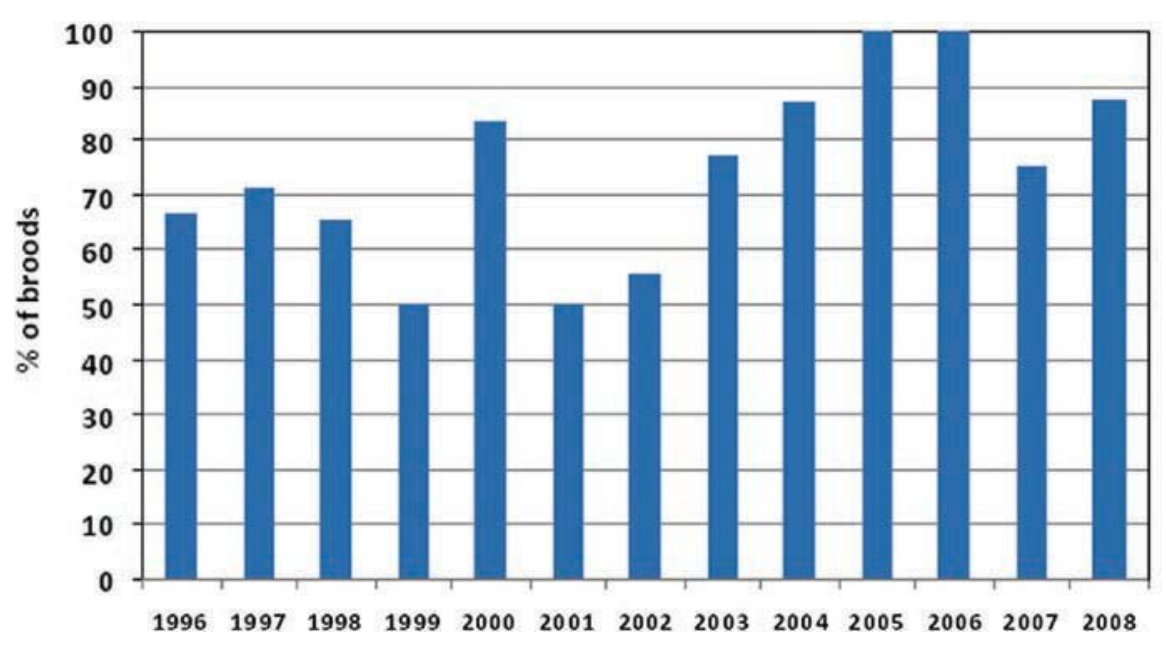

Fig. 30.4 Percentage of broods of marbled teal at Veta la Palma aquaculture poools to the total study area over the period from 1996 to 2008

broods seen. One of the main causes for this is the high predation rate, mainly by rats Rattus spp. in the natural marshes (Navarro and Robledano 1995; Green 1998), and by red fox Vulpes vulpes in Veta la Palma.

In keeping with the trend for pairs, the trend in the number of broods shows a slight decrease. Critically, however, between $50 \%$ and $100 \%$ of the broods have been found in Veta la Palma aquaculture pools every year (Fig. 30.4), with this percentage increasing significantly during the study period $(\mathrm{p}=0.0033)$. This means that this area of man-made habitat, where broods are able to complete their development (marbled teal nests later than other duck species in the area, see Green 1998) is becoming crucial to the survival of the species in DNS.

The Spanish population of marbled teal is an important part of the Western Mediterranean population (Green et al. 2004), and these data show that DNS is, after the wetlands of the Southern Alicante region (Gómez et al. 2006), the second most important area for the species in the country.

\section{Ferruginous Duck}

Valverde (1960) reckoned that about 500 ferruginous duck pairs bred in the Guadalquivir Marshes at the beginning of the last century, compared to just a dozen at the end of the 1950s.

Between 1970 and 1992, breeding was confirmed in only three seasons, in 1984 (two broods), 1987 (one brood) and in 1989 (some fledglings) (Green 2004). During the 5-year period 1992-1996, more than 125 captive birds were released: first in the El Acebuche lagoon complex (DNS) and later in Portil lagoon, in the 
province of Huelva (Green 2004). Since then, breeding was confirmed at El Acebuche in 1993 (three pairs), 1994 (two broods) and 1996 (one brood).

Despite annual sightings of males and females at El Acebuche, the next confirmed breeding was in 1999, when a female with four ducklings was seen in one of the interdunal lagoons. Breeding was also confirmed in 2000 at El Acebuche, with the sighting of a female with five small ducklings in the middle of August, and an adult female with two juveniles (male and female) in October, presumably the survivors.

Although there have been breeding season sightings in 2001, 2002 and 2003, and winter sightings since then, there have been no subsequent breeding records at DNS. These data suggest that the releases undertaken in the 1990s have not aided the recovery of the population in Doñana and the Guadalquivir Marshes, the most important in all of Spain (Green 2004). This could be because the main cause of the decline (habitat degradation) still persists. Ferruginous ducks seem to require wetlands that are rich in emergent, floating vegetation and submerged macrophytes (Green 2004).

\section{White-Headed Duck}

The coordinated censuses from 2003/2004 to 2007/2008 have shown that this species is currently much more abundant in DNS and its surrounding areas in autumn and winter than during the breeding season. The main wintering locations are the fishponds of Veta la Palma and the Tarelo lagoon.

The first Spanish records for white-headed ducks were at Doñana and the Guadalquivir Marshes (see review in Torres Esquivias et al. 1986). According to Amat and Sánchez (1982), some 200 pairs bred in this area in the 1950s. However, the species stopped breeding in Doana and the Guadalquivir Marshes in the late 1960s (Ree 1973), and there were no further breeding records until 1985, when between three and 10 broods seem to survive (García et al. 1986; Clarita 1986). The following year at least one brood hatched in one of the interdunal lagoons (García et al. 1989). After this, there was no evidence of breeding in the natural marshes until 2007, though 11 ducklings were seen at Tarelo lagoon in June 1993, with successful breeding also confirmed there in 1994 and 1995 (Torres Esquivias and Moreno-Arroyo 2000).

The number of estimated broods in DNS and surrounding areas from 1996 to 2008 are shown in Fig. 30.5. Due to the low numbers, it is not possible to establish a statistically significant trend. Note, however, that this population represents only a small percentage of the total Spanish population of around 2,300 birds (Torres Esquivias 2004).

These data suggest that Tarelo lagoon has diminished in importance as a breeding site for the species over the last 3 years. There was no nesting there in 2002 and 2003, which coincides with a reduction in benthic chironomid biomass related to the hypereutrophy and episodes of anoxic conditions (Serrano et al. 2004), 


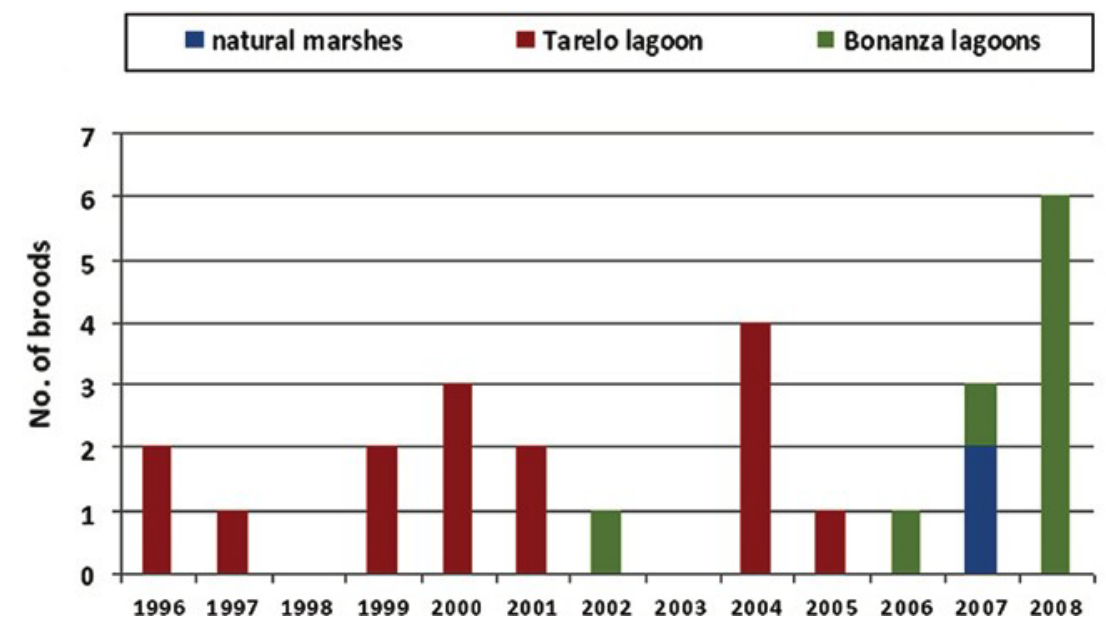

Fig. 30.5 Number of estimated broods of the white-headed duck in Doñana Natural Space (natural marsh and Tarelo lagoon) and Bonanza lagoons over the period from 1996 to 2008

which may also have happened subsequently. It seems unlikely that this species will return to nest in the natural marshes on a regular basis, given that its disappearance is due to the lack of deep and semi-permanent waters suitable for breeding (Green and Figuerola 2003).

For this reason, urgent measures are needed to protect the Bonanza lagoons, where the species has been breeding in recent years, as these lagoons are located in an area of intensive farming, where the risks of pollution and degradation due to hyper-eutrophication are high. Similarly, illegal hunting and disturbance by domestic animals in the lagoons pose a serious threat to the breeding population.

\section{Bittern}

According to Valverde (1960), the bittern was a scarce but well-distributed nesting species in the Marshes to the late 1950s. According to Urdiales (unpublished report), it certainly bred in what today represents the National Park until the beginning of the 1980s, when large areas occupied by the species and dominated by bulrush Typha sp. disappeared; meanwhile, in the marshes to the north of the present DNS, it seems that it bred until the middle of the 1980s, when all the northern "lucios" were drained.

In 1991, this last author detected eight territories in the Guadalquivir Marshes (five of them located in the "Eastern Branch" of the Guadalquivir River, where bitterns were heard every year). Thereafter, there were no records during a cycle of drought that lasted from 1992 until 1995 (Fig. 30.2). 
Subsequently, despite abundant rainfall in several years, with the exception of one bird seen near El Rocío on 17th April 1999 (Arce and Sal 2001), the only observations were outside the breeding season. There was no evidence of breeding until 2002, when four territorial males were present in the natural marshes throughout the breeding season. As nests are very difficult to locate, there is no evidence that the species bred, or evidence to the contrary.

In the 2003 season, 12 territorial males were present, and breeding was confirmed in the natural marshes of the National Park and in Veta la Palma (Ibáñez et al. 2004). In 2004, however, 11 territorial males were recorded, but there was no evidence of fledged young and at least three of the four nests were lost, two reoccupied by purple heron Ardea purpurea and one raided by wild boar Sus scrofa (Espinar and Ibáñez 2004).

The drought of 2005 prevented breeding in Doñana, while in 2006 five territorial males were seen but there was no evidence of breeding.

In the 2007 season, nine territorial males were reported and five nests located, two of which were reoccupied by purple heron and one raided by wild boar. The others were successful in producing young, though only one was seen to fledge.

In 2008, eight territorial males were reported at the beginning of the breeding season, but these had stopped calling by the end of April, suggesting that they all left the area earlier than normal because of the low water level in the natural marshes. This year the total annual rainfall was close to the historical average (Fig. 30.2), but for the first time the rainiest month was April, in the middle of the spring.

Although not statistically significant, the trend in the number of territorial males since the species began to nest again in DNS, shows a slight increase. As a consequence, DNS is now the second most important breeding area for this species in Spain after the middle Ebro river valley, which supports between 12 and 17 territorial males (Bertolero and Soto-Largo 2004). However, it must be born in mind that a long drought could threaten the survival of this species in DNS.

One problem we have mentioned is the reoccupation of bittern nests by purple herons, which happens in areas of wetland fenced to exclude livestock and encourage regeneration of common reed Phragmites australis. This fencing has resulted in dense areas of reedbed where colonies of purple heron have proliferated, and where bitterns have also settled. The problem does not occur when bitterns nest in wetland dominated by alkali bulrush Bolboschoenus maritimus, though they can be easy prey for wild boar in these areas if the water level is not sufficiently high.

\section{Squacco Heron}

According to Valverde (1960), the 60-80 pairs of squacco heron that nested in the Guadalquivir Marshes during the 1950s in the famous "Pajarera" (a big colony of herons and spoonbills Platalea leucorodia) of Doñana, was the most important population in Western Europe. During the 1960s and 1970s, their numbers in this colony declined, until in 1980 only two pairs were seen (Aguilera and Sañudo 1986). 
Meanwhile at La Rocina, near El Rocío, an estimated 100 to 200 pairs was present during the early 1970s (Ree 1973), but this colony disappeared in 1974 (Castroviejo 1993). Fortunately, since 1974, the species has taken refuge on the edge of the Guadalquivir River, first in La Isleta and later in Los Olivillos (La Puebla del Río, Sevilla). In 1974, some 50 pairs were present (Castroviejo 1993) and, since then, between 5 and 70 pairs have bred in the area every year.

Although one pair was reported in the "Pajarera" in 1990, the species really came back to breed in DNS in 1996 (Table 30.1), after the long period of drought of the early 1990s (Fig. 30.2). This time, the species settled in the Casas "lucio" of FAO, where it formed a mixed colony with purple herons and glossy ibis Plegadis falcinellus. This is an area protected from large herbivores and terrestrial predators, which can be supplied with water from a well, and where the species nests in both bulrush Typha dominguensis and African tamarisk Tamarix africana.

Since then, this colony has consolidated (Table 30.1) and, except in years of severe drought, such as 1999 and 2005 (Fig. 30.2), these three species have bred. Currently, this is one of the most important colonies for Ciconiiforms in the whole of Europe. Also in 1996, a pair bred successfully in a mixed colony in a pine forest by the El Acebuche lagoon (Máñez and Garrido 1997); but this was an isolated incident.

In 1998, the squacco heron returned to the "Pajarera" as a breeding species, but in 1999 it did not nest at all within DNS due to the drought. The following year, the number of pairs in DNS was low, no doubt affected by the drought of the previous year. However in 2001, the number of pairs in the FAO and the "Pajarera" increased substantially, and the species formed a third colony in DNS, in Juncabalejo, an area of common reed fenced to protect it from herbivores (Fig. 30.1). However, due to the low water table in this area, a wild boar raided eight nests and an Egyptian mongoose Herpestes ichneumon ate some of the chicks from the remaining nests.

In 2002, the number of pairs breeding in the three colonies increased within DNS, while in 2003 and 2004 this increase was only seen in the FAO. The severe drought of 2005 practically prevented this species from breeding in DNS, and only two pairs were reported in a new colony located on some tamarisks in Entremuros, close to Ford of Don Simón (Natural Park), although successful breeding could not be confirmed. In 2006, the breeding population in DNS recovered and reached 84 pairs, of

Table 30.1 Minimum number of estimated breeding pairs of squacco heron at the colonies of Doñana Natural Space over the period from 1996 to 2008. No squacco herons bred in 1999

\begin{tabular}{lrrrrrrrrrrrr}
\hline Colony/year & 96 & 97 & 98 & 00 & 01 & 02 & 03 & 04 & 05 & 06 & 07 & 08 \\
\hline Pajarera & 0 & 0 & 5 & 5 & 22 & 29 & 26 & 17 & 0 & 1 & 31 & 0 \\
Acebuche & 1 & 0 & 0 & 0 & 0 & 0 & 0 & 0 & 0 & 0 & 0 & 0 \\
FAO & 130 & 100 & 45 & 15 & 70 & 160 & 331 & 389 & 0 & 80 & 100 & 100 \\
Juncabalejo & & & & & 25 & 67 & 3 & 24 & 0 & 0 & 40 & 0 \\
Ford of Don & & & & & & & & & 2 & 2 & 0 & 2 \\
$\quad$ Simón & & & & & & & & & & & & \\
$\quad \begin{array}{l}\text { Tarelo lagoon } \\
\text { Total }\end{array}$ & 131 & 100 & 50 & 20 & 117 & 256 & 360 & 430 & 2 & 84 & 171 & 108 \\
\hline
\end{tabular}


which 95\% where in the FAO area. There was also confirmation, for the first time, of breeding (one fledgling) in a colony of small herons in Tarelo lagoon.

In 2007, the breeding population in DNS doubled by comparison with 2006, but this population increase was not sustained in 2008, when low water levels contributed to a lack of colonies in the inner National Park (Pajarera and Juncabalejo).

Despite the trend in number of pairs from 1996 to 2008 showing a slight decrease, the DNS population is the second most important in Spain, second only to that of the Ebro delta, in Tarragona (Pérez-Aranda et al. 2003). It seems that excluding large herbivores from areas of marshland vegetation may have contributed to this.

\section{Black Stork}

Valverde (1960) refers to concrete evidence of black storks (Fig. 30.6) nesting within the limits of the present DNS, and the species is included in the list of birds that nested in Santa Olalla, the main interdunal lagoon in 1774. There has been no other confirmed breeding in the area that today corresponds to DNS, although in 2007, there was a late attempt to nest in a pine forest in Doñana National Park, but the birds left before egg-laying.

The monitoring of this species, mainly summer resident in Spain, has detected the wintering in the study area since the early eighties, which has grown from a few individuals to over 300 in January 2007, although this number dropped by 60\% over the subsequent two winters, returning to numbers similar to those in 2004 and 2005.

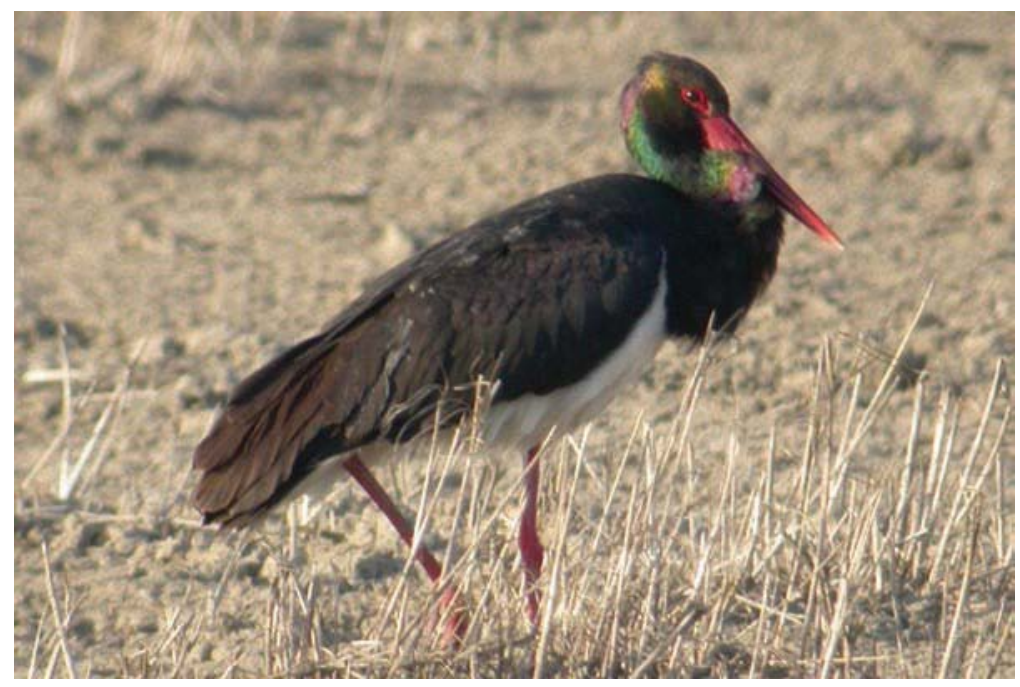

Fig. 30.6 A black stork at Doñana Natural Space. Photo by J.A. Sencianes/EBD-CSIC 


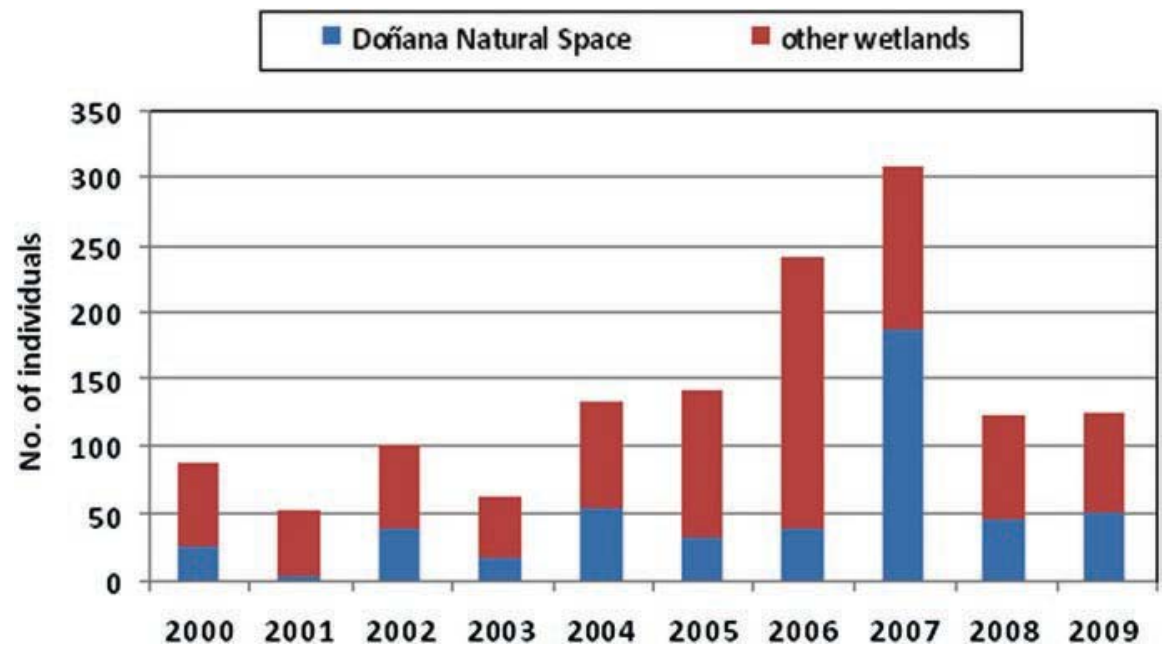

Fig. 30.7 Number of individuals of black stork in the censuses of January 2000 to 2009 at Doñana Natural Space and other wetlands of the Guadalquivir Marshes

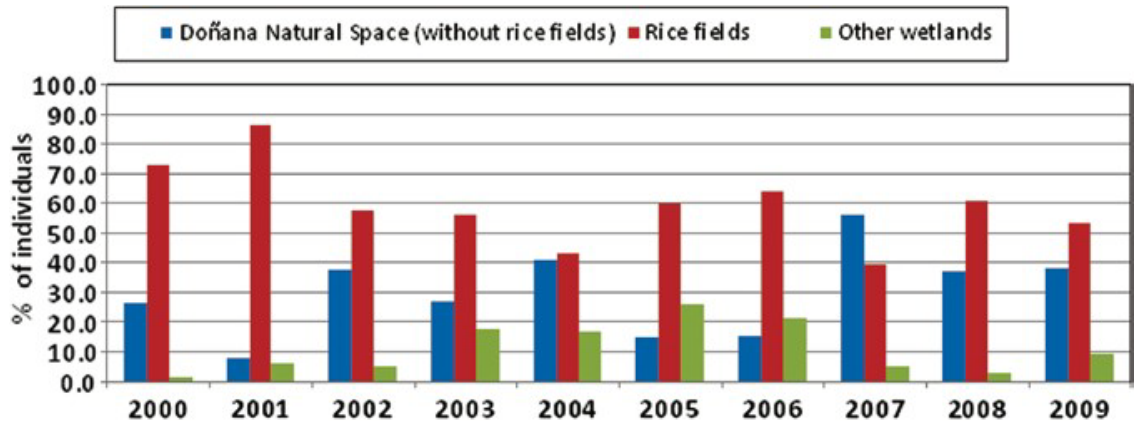

Fig. 30.8 Percentage of individuals of black stork observed from census in January 2000 to 2009 in Doñana Natural Space (excluding rice fields), rice fields and the other wetlands in the Guadalquivir Marshes

However, these numbers mean that the Gualdalquivir Marshes are the main wintering ground of the species in Spain.

Overall the trend in numbers of wintering black stork between the years 2000 and 2009 (Fig. 30.7) shows a slight increase; this corresponds to significant increment in DNS ( $\mathrm{p}<0.05), 18.6 \%$ annually, while not being statistically significant across the rest of the wetlands.

If we break down the census taking into account sightings within DNS (except the small rice field zone within it, which occupies $1.3 \%$ of the area), in all the rice fields and in the rest of wetlands censused (Fig. 30.8), the highest count every year (except one) is 
in the rice fields. This is of great importance from a conservation perspective, since at least $93 \%$ of the rice field area that is cultivated every year (ranging from a minimum of 22,000 ha to a maximum of 37,000 ha from 2000 and 2007) is not protected.

\section{Red-Knobbed Coot}

Valverde (1960) stated that, according to professional egg collectors, the redknobbed coot (Fig. 30.9) was formerly common in the wetlands and nested in a 1:10 ratio with common coot Fulica atra. By the end of the 1950s, however, the species nested only in very small numbers, raising fears of rapid extinction in the area. Although still rare, the species continued nesting until the end of the 1980s, with a breeding population of between 10 and 20 pairs and a ratio of 1 red-knobbed coot to every 630-710 common coots (Máñez 1991).

In 1990, a year of abundant rainfall, it was estimated that there were only three pairs in the area, and during the 3-year period between 1996 and 1998, also with abundant rainfall, very few birds were recorded during the breeding season and only one nest (in 1996) was found.

However, at the end of the winter of 2000/2001, sightings increased, and at least 37 pairs were seen in DNS in spring 2001 (32 in the National Park and five in the marsh channel of Guadiamar), six of these broods were monitored. The reasons for this spectacular increase are not certain, but it seems logical to assume that it was influenced by habitat degradation at some of the best breeding locations for the species in Morocco (Green et al. 2002), and augmented by the release of birds from captive breeding programs in Andalusia and Valencia (Amat and Raya 2004).

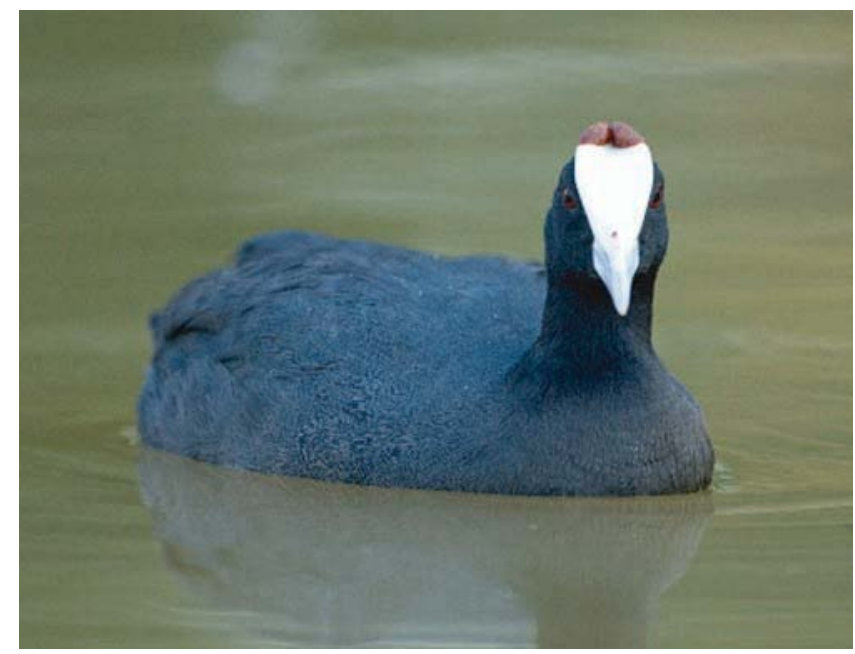

Fig. 30.9 Adult red-knobbed coot in breeding plumage. Photo by Héctor Garrido/EBD-CSIC 
In 2002, estimates suggested there were 50-54 pairs in DNS, of which $80 \%$ were in the National Park, and the rest in the marsh channel of Guadiamar. In 2003, 73-82 pairs were detected in DNS, of which 90-93\% were in the National Park, $5.5-7 \%$ in the marsh channel of Guadiamar and the rest in Veta la Palma. Finally, in 2004, there were between 91-111 pairs in DNS, of which $>95 \%$ were in the National Park and the rest in the marsh channel of Guadiamar. These surveys indicated that DNS was again the most important breeding area for the species in Spain, after the barren 1990s, when the species found refuge mainly in the Cádiz lagoons (Amat and Raya 2004). Moreover, within the Guadalquivir Marshes, the National Park is the most important area, especially the marsh area close to Juncabalejo, where the two main marsh channels meet.

Subsequently, in 2005, a very dry year, there was no sign of breeding, and the following year only one nest was detected in the whole of DNS, in the natural marshes of the National Park. As no chicks were seen in the area, which dried up soon after, we can assume that breeding was not successful.

However, the population partially recovered in the spring of 2007, where an estimated 64 pairs gathered mainly in the marsh area close to Juncabalejo, where they bred fairly successfully. Only four pairs were studied outside this area, three in the marsh channel of Guadiamar, where no chicks hatched, and one at El Acebuche lagoon, a new location for the species, where two chicks fledged.

The poor hydrological conditions during 2008 prevented the species from settling in the natural marshes of the National Park, nor were there sightings of pairs in the marsh channel of Guadiamar. Only two pairs were seen: one that raised a chick at El Acebuche lagoon (F. Robles, pers. comm.) and the other at El Rocío Marshes.

The trend in the number of pairs of red-knobbed coot since its return as a breeding species shows a slight decrease: this, however, is undoubtedly influenced by the years when numbers were very low and when the species was absent.

\section{Conclusions}

The long-term surveillance of the endangered breeding species suggests that the three duck species have declined in DNS by comparison with the populations in the 1950s. Ferruginous duck rarely breeds any more, and the others have found refuge in artificial habitats, marbled teal in the aquaculture pools of Veta la Palma and white-headed duck in man-made lagoons.

These population declines are related to changes in the natural marshes, with the disappearance of deep water and semi-permanent areas, suitable for the two diving species, and a shorter annual period of flooding, affecting all three species (Green and Figuerola 2003).

In the case of the marbled teal, predation by rats and disturbance (by humans and livestock) in the natural wetland led to the creation of a "Reserve Zone" located in the southern marsh in 2005. These problems are yet to be fully eliminated.

The remaining species are faring considerably better. The bittern, which was extinct as a breeding species in the area during the 1980s and 1990s, has recovered 
part of its original population in the early years of the twenty-first century, and the squacco heron population is larger than it was in the 1950s, and with a substantial increase in the number of colonies in DNS. A few consecutive years of adequate rainfall, combined with the various measures taken by the Management Body of DNS, such as (a) the reduction of livestock in the National Park, (b) the fencing of areas in the natural marshes (to exclude livestock and allow regeneration of marsh vegetation), and (c) improved exchange of water with the estuary (allowing fish to enter from the Guadalquivir River), appear to have aided this recovery.

The populations of red-knobbed coot are higher than those of the 1950s, although much lower than previously. As this species seems to require fresh water wetlands and clear water with a high diversity and coverage of submerged plants (Green et al. 2002), it can be construed that some areas of the natural marshes have been in optimum condition during recent years. Nevertheless, during the open season for hunting in Andalusia, hunting common coots should be banned at sites that provide shelter for red-knobbed coots, a measure that is already in place in some areas.

In the case of the black stork, wintering depends to a large extent on the existence of rice fields, a crop of great importance for many species of wintering waterbird in the Guadalquivir Marshes (Toral and Figuerola, unpublished report). Therefore its replacement by any other crop or use, with the exception of the restoration of the natural wetland, would be detrimental for this species and many others.

In summary, survey and monitoring of the bird populations is a basic and essential tool for both researchers and managers. The researchers can then study the relationships between the changes in the bird community and the temporary changes in the wetland conditions (Green and Figuerola 2003). They can also assess the adequacy of the management measures implemented by managers, and may recommend that these measures are reviewed within the proposed conservation objectives.

Acknowledegments This work would not have been possible without the help and collaboration of different administrations that have managed the current DNS during these years of research. Likewise, colleagues in Doñana Biological Station and in DNS, as well as a good number of volunteers have contributed information and collaborated in the work. Ricardo Diaz-Deldado produced Fig. 30.1. Thanks also to Olga Ceballos and Clive Hurford for correcting the drafts. Since 2003, many of the monitoring tasks are performed through an agreement with the Administration of DNS (Autonomous Body for National Parks of the National Ministry of Environment until 2006, and the Regional Environment Authority of Andalusia since 2007), and censuses of waterbirds have been funded through a contract with Environmental Management Company (EGMASA), of the Regional Environment Authority of Andalusia.

\section{References}

Aguilera E, Sañudo J (1986) Pasado y presente de las colonias de Ciconiformes en Doñana y Odiel. Bios 2:11-13 (in Spanish)

Amat JA, Raya C (2004) Focha moruna, Fulica cristata. In: Madroño A, González C, Atienza JC (eds) Libro Rojo de las Aves de España. Dirección General para la Biodiversidad-SEO/ BirdLife, Madrid, pp 199-202 (in Spanish)

Amat JA, Sánchez A (1982) Biología y ecología de la malvasía (Oxyura leucocephala) en Andalucía. Doñana Acta Vertebrata IX:251-320 (in Spanish) 
Arce LM, Sal V (2001) Noticiario Ornitológico 2001 (1). Avetoro común Botaurus stellaris. Ardeola 48(1):137 (in Spanish)

Bertolero A, Soto-Largo E (2004) Avetoro común, Botaurus stellaris. In: Madroño A, González C, Atienza JC (eds) Libro Rojo de las Aves de España. Dirección General para la BiodiversidadSEO/BirdLife, Madrid, pp 65-69 (in Spanish)

BirdLife International (2008) Species factsheet. Available at http://www.birdlife.org (accessed on 3 March 2009)

Bravo MA, Montes C (1993) Inventario de las formaciones palustres del manto eólico del Parque Nacional de Doñana (SW España). Actas del VI Congreso Español de Limnología Granada, pp 31-43 (in Spanish)

Castroviejo J (1993) Memoria del mapa del Parque Nacional de Doñana. Consejo Superior de Investigaciones Científicas y Agencia de Medio Ambiente de la Junta de Andalucía (in Spanish), Sevilla

Clarita P (1986) Noticiario Ornitológico. Malvasía (Oxyura leucocephala): Nidificación comprobada en las marismas del Guadalquivir. Ardeola 33(1-2):206 (in Spanish)

Espinar JM, Ibáñez F (2004) Noticiario Ornitológico. Avetoro común (Botaurus stellaris). Ardeola 51(2):543-544 (in Spanish)

García L, Calderón J, Castroviejo J (1986) Informe sobre la reproducción de las aves del Parque Nacional de Doñana en 1985. Estación Biológica de Doñana, Sevilla (in Spanish)

García L, Calderón J, Castroviejo J (1989) Las aves de Doñana y su entorno. Estación Biológica de Doñana (CSIC) - Cooperativa Marismas del Rocío (in Spanish)

García L, Ibáñez F, Garrido H, Arroyo JL, Máñez M, Calderón J (2000) Prontuario de las Aves de Doñana. Anuario Ornitológico de Doñana, $\mathrm{n}^{\circ}$ 0, Diciembre 2000. Estación Biológica de Doñana y Ayuntamiento de Almonte, Almonte (Huelva) (in Spanish)

Garrido H, Arroyo JL, García L, Ibáñez F, Máñez M, Vázquez M (2004) Anuario Ornitológico de Doñana, no 1 (Septiembre 1999 - agosto 2001). Estación Biológica de Doñana y Ayuntamiento de Almonte, Almonte (Huelva) (in Spanish)

Gómez JA, Dies JI, Vilalta M (2006) Las aves acuáticas de la Comunitat Valenciana: censos y evolución de las poblaciones (1984-2004). Conselleria de Territori i Habitatge, Generalitat Valenciana, València (in Spanish)

Green AJ (1998) Clutch size, brood size and brood emergence in the Marbled Teal Marmaronetta angustirostris in the Marismas del Guadalquivir, southwest Spain. Ibis 140:670-675

Green AJ (2000) The habitat requirements of the Marbled Teal (Marmaronetta angustirostris), Ménétr., a review. In: Comín FA, Herrera JA, Ramírez J (eds) Limnology and aquatic birds: Monitoring, modelling and management. Proceedings of the 2nd SIL international congress. Universidad Autónoma del Yucatán, Mérida, pp 131-140

Green AJ (2004) Porrón pardo, Aythya nyroca. In: Madroño A, González C, Atienza JC (eds) Libro Rojo de las Aves de España. Dirección General para la Biodiversidad-SEO/BirdLife, Madrid, pp 108-110 (in Spanish)

Green AJ, Figuerola J (2003) Aves acuáticas como bioindicadores en los humedales. In Paracuellos M (ed) Ecología, manejo y conservación de los humedales. Instituto de Estudios Almerienses, Almería, pp 47-60 (in Spanish)

Green AJ, El Hamzaoui M, El Agbani MA, Franchimont J (2002) The conservation status of Moroccan wetland with particular reference to waterbirds and to changes since 1978. Biol Conserv 104:71-82

Green AJ, Echevarría JL, Ferrández M (2004) Cerceta pardilla, Marmaronetta angustirostris. In Madroño A, González C, Atienza JC (eds) Libro Rojo de las Aves de España. Dirección General para la Biodiversidad-SEO/BirdLife, Madrid, pp 100-104 (in Spanish)

Ibáñez F, Espinar JM, Máñez M (2004) El retorno del avetoro a Doñana. Quercus 225:14-19 (in Spanish)

Madroño A, González C, Atienza JC (eds) (2004) Libro Rojo de las Aves de España. Dirección General para la Biodiversidad-SEO/BirdLife (in Spanish), Madrid

Máñez M (1991) Estado actual en el Parque Nacional de Doñana de las especies de aves incluidas en la "Lista Roja de los vertebrados de España" en las categorías de "En peligro" y 
“Vulnerable”. Jornadas de Zonas Húmedas Andaluzas. Fuente de Piedra, 20-22 Abril 1990, pp 41-49 (in Spanish)

Máñez M, Garrido H (1997) Noticiario Ornitológico. Garcilla cangrejera Ardeola ralloides. Ardeola 43(2):240-241 (in Spanish)

Montes C, Borja F, Bravo MA, Moreira JM (1998) Reconocimiento Biofísico de Espacios Naturales Protegidos. Doñana: Una Aproximación Ecosistémica. Consejería de Medio Ambiente. Junta de Andalucía, Sevilla (in Spanish)

Navarro JD, Robledano F (1995) La cerceta pardilla (Marmaronetta angustirostris) en España. ICONA Colección Técnica (in Spanish)

Pannekoek J, Van Strien A (1998) TRIM 3 manual (trends \& indices for monitoring data). JM Voorburg, Statistcs Netherlands

Pérez-Aranda D, Ibáñez F, García L, Jiménez M, Garrido H, Máñez M (2003) Garcilla Cangrejera, Ardeola ralloides. In: Martí R, Del Moral JC (eds) Atlas de las Aves Reproductoras de España. Dirección General de Conservación de la Naturaleza - Sociedad Española de Ornitología, Madrid, pp 110-111 (in Spanish)

Ree V (1973) Dagens avifaunistiske situasjon i Las Marismas i Sør-Spania. Sterna 12(4):225-268 (in Norwegian)

Serrano L, Reina M, Arechederra A, Casco MA, Toja J (2004) Limnological description of the Tarelo lagoon (SW Spain). Limnetica 23(1-2):1-10

Sutherland WJ (1996) Ecological census techniques: A handbook. Cambridge University Press, Cambridge

Tellería JL (1986) Manual para el censo de los Vertebrados Terrestres. Editorial Raíces, Madrid (in Spanish)

Torres Esquivias JA (2004) Malvasía cabeciblanca, Oxyura leucocephala. In Madroño A, González C, Atienza JC (eds) Libro Rojo de las Aves de España. Dirección General para la Biodiversidad-SEO/BirdLife, Madrid, pp 111-113 (in Spanish)

Torres Esquivias JA, Moreno-Arroyo B (2000) La recuperación de la malvasía cabeciblanca (Oxyura leucocephala) en España durante el último decenio del siglo XX. Oxyura 10(1):5-51 (in Spanish)

Torres Esquivias JA, Arenas R, Ayala JM (1986) Evolución histórica de la población española de malvasía (Oxyura leucocephala). Oxyura 3(1):5-17 (in Spanish)

Valverde JA (1960) Vertebrados de las Marismas del Guadalquivir (introducción a su estudio ecológico). Archivos del Instituto de Aclimatación IX:1-168 (in Spanish) 